\title{
TEACHERS' PERCEPTION OF SOCIAL STUDIES AND CIVIC EDUCATION AS INSTRUMENTS FOR STRENGTHENING THE FIGHT AGAINST CORRUPT PRACTICES IN NIGERIA
}

\section{THERESA EBIERE DORGU}

Niger Delta University, Wilberforce Island, Nigeria.

\author{
AMOS ADEKUNLE ADEDIRAN ISAAC SOBOLA \\ Department of Social Studies School of Arts and Social Sciences \\ Federal college of Education, Osiele Abeokuta, Nigeria.
}

\begin{abstract}
The study examined teacher's perception of social studies and civic education in strengthening the EFCC for corruption eradication in contemporary Nigeria society. Survey research design was adopted. Three research questions and three hypotheses were posed to guide the investigation. Population of the study comprised of all the Social Studies and Civic Education teachers both male and female in the Odeda Local Government Area of Ogun State. Stratified random sampling techniques was applied to select of 260 respondents as the sample but 220 was used for analysis while structured questionnaire which was designed in Likert form was used for data collection since all the respondents were literate and to save time. The stated hypotheses were tested using chi-square $\left(X^{2}\right)$ statistic and results presented in tables. The result revealed, among others, that teachers can use social studies to strengthen the EFCC for corruption eradication. After the conclusion, the following were some of the recommendations made: school management, religious organization, non-governmental organizations and the entire citizenry must stand up against corruption and complement government efforts in anticorruption crusade. In addition, government should support EFCC in eradicating corrupt practice in the contemporary Nigerian society.
\end{abstract}

Keywords: Economic and Financial Crimes, Corrupt Practices, Civic Education. DOI: $\quad$ https://doi.org/10.35386/ser.v18i1.28

\section{Introduction}

Social Studies education in Nigeria is geared towards producing individuals who will not only possess the capabilities to solve their problems but also contribute to solve societal problems. As opined by Okam (2009), the purpose of social studies education is to prepare citizens who will perpetuate and improve their society. This could only be achieved if the child is equipped with enabling cognitive, affective and psychomotor dimension of social studies education which is to introduce the students to the mode of critical thinking involved in decision making and problems solving. That is the reason why many scholars viewed social studies education as a discipline that focuses on helping students to acquire skills and value that will enable them to recognise and solve human problems through carefully analysis and sound decision making (Haruna \& Liman, 2013). As a functional disciplie according to Haruna and Liman (2013), Social Studies exposes learners to learning experiences, acquisition of skills and attitudes that will equip them to face challenges of life either individually or in a group. This means that social studies education focuses on man as the central figure and its roles to maintain social ability and social reconstruction.

Civic education according to Adediran, Lijadu and Olugbuyi (2017) is embedded in social studies education and has been termed as the process by which the public is made aware of social and political rights and responsibilities as well as principles and 
practices of action. Civic education is intended to build and heightened awareness of the gaps between law and practice. It can provide a link between education and action, empowering actions with the tools, skills and attitude necessary to influence change, strengthening the citizen's movement and influence. Civic education is therefore the knowledge, information, aspiration, expectation a nation gives to its citizens to know their right and duties.

The Economic and Financial Crime Commission was created and empowered to prevent, investigate and prosecute economic and financial crimes as entailed in the banks and other financial institution (BOF) Act 1991, Act 1995, the failed banks (recovery of debts) and financial malpractices in banks, Act 1994, the advance fee fraud and other fraud related offences Act 1995, the economic and financial crime commission Act 2004 and the money laundering and prohibition Act 2004.

Agara and Olasinmoyein Baruwa and Adediran (2014) enunciated that the EFCC is expected to actualize good governance and actualize through diverse strategies viz:

1. Promulgation of law against graft-Independent Corrupt Practices and other Related Offences Commission (ICPC) Act,Economic and Financial Crime Commission (EFCC) Act, and money laundering (prohibition) Act 2004.

2. Strengthening of anti-corruption and other economic crimes institutions for effective law enforcement.

3. Prosecution and conviction of high-ranking administrative officials.

4. Tracing, seizing and confiscating of all stolen properties.

5. Institution of the due process mechanism in public sector procurements.

6. Privatization of failing public institutions and creating an enabling environment for effective private-public partnership.

7. Monthly publication of distributable revenue from the federation account to the different tears of government.

8. Institution of transparencies in the oil and gas sector through the work of the Extractive Industries Transparency Initiative (EITI).

Agboin Baruwa and Adediran (2014) said that with the strategies enumerated above, the EFCC is empowered with the power to investigate, prevents and prosecute offenders who engage in money laundering, embezzlement, bribery, looting and any form of corrupt practices like illegal arms deals, smuggling, human trafficking, child labour, illegal oil bunkering, illegal mining, tax evasion, and foreign exchange. EFCC also has mandates over other forms of malpractices which include counterfeiting of currency, theft of government property, and piracy open market abuse, dumping of toxic waste, and prohibited good (section 40, EFCC establishment Act 2004). The commission is also responsible for identifying, tracing, freezing, confiscating or seizing proceeds derived from terrorist activities. Furthermore, Ribadu in Ejike (2012) submitted that in addition to other laws relating to economic and financial crimes, EFCC has been empowered to enforce all the pre-1999 anticorruption and anti-money laundering laws. Punishment prescribed in the EFCC establishment Act ranges from combination of payment of fine for feature of assets and five years' imprisonment depending in the nature and gravity of the offence, conviction for terrorist financing and terrorist activities attracts life imprisonment. 
These are some of the strategies and activities of EFCC in eradicating corrupt practices in Nigeria. Ejike (2012) explained that a total asset worth, 755, 924, 635, 69 was received and forfeited to various victims of crimes which included government agencies and departments private individuals and organizations. This is in addition to the recovery of over $\$ 170$ million between 2010 and 2012 made through settlements. In addition, in the first quarter of 2013, the Commission recorded 33 convictions, 5 of the convictions were on illegal transportation of foreign currency contrary to the money laundering (prohibition) Act. The sum of $\$ 144,214,5$ and $\$ 2,705,000.00$ were ordered forfeited to the federal government of Nigeria treasury. The remaining 28 were for offences of obtaining money by false pretense, forgery, illegal dealing on petroleum product.

In the same period, EFCC collaborated with metropolitan police in the investigation, conviction and sentencing of Mr. James Ibori, a former Governor of Delta State by the Crown Court in South-wark, London on February 27, 2012 to 13 years imprisonment for money laundering and fraud. Also, the former Managing Director of Intercontinental Bank Plc, Mr. Ereastus Akingbola was prosecuted before the Royal Commercial Court in London on July 311, 2012 in which the court ordered the forfeiture of approximately N65 billion in favour of Access bank plc (Ejike, 2012).

Also, Ejike (2012) revealed that the EFCC played a vital role in the prosecution of cases providing the UK with critical assistance during the investigation. The EFCC's partnership with U.K authorities in these cases represents best practices in International Corporation as provided by the United Nations Convention Against Corruption (UNCAC).

The Criminal Prosecution of top Politically Exposed Persons (CPEP) also received attention of the commission. This is consistent with its top-down approach to combating corruption. To this end, five former state governors and a former speaker of house of representative including a cabinet minister were charged to court between 2005 and 2012 for corrupt practices bordering on contract fraud and/ or abuse of office.

In January 2012, some dishonest marketers of petroleum products swindled the federal government of over N.7 trillion under the Petroleum Support Fund (PSF) Scheme. This sheer magnitude of the monumental fraud prompted national protests led by labour unions and civil society organization against the federal government's proposal to completely remove the fuel subsidy scheme. According to Baruwa and Adediran (2014) EFCC has so far investigated and arraigned 13 companies including their management staff and directors in court with sum of N12.4 billion involved. The commission has been able to recover over N3million from all the indication about the strategies and activities of EFCC and its partners. Nigeria was delisted from the infamous lists of non-cooperative nations in the fight against corruption and money laundering by the financial act task force (FETF).

Social Studies has been described as societal interdisciplinary problem solving, interactive, informative, and integrated subject that is capable of strengthening EFCC to eradicate corrupt practices in Nigeria, social studies education is therefore essentially meant to produce society devoid of selfishness, callousness, greedy, violence, lopsidedness, cheating, embezzlement, resources mismanagement and other 
social vices that are antithetic to the communal living and peaceful co-existence of human society (Adediran \& Ojetunde, 2016). Seeing the way and manner corruption has eaten deep into the fabric of Nigerian society, the interdisciplinary nature of social studies education can be best way of teaching people on how to handle public fund. Social studies and civic education are thus programmes which seem to be uniquely assigned with citizenship. They are programmes of general education for young people focusing on the study of human, society, institution and relationship with nature and with one another (Yusuf, 2005). As programmes of general education, social studies and civic education therefore prepare young people to function as effective citizen who will love their own country at heart so as not to jeopardise the development and progress of their nation. With that in mind, either leaders or followers may not embezzle the country's treasury for the down fall of their nation. In the same vein, Haruna and Liman (2013), view social studies and civic education as programmes of study that a society use to instill in people, the knowledge, attributes, values, and skills that will make them to be patriotic to their country.

Oladimeji (2017) examined corruption and economic recession: the need for civic learning, he advocated that national values of honesty, obedience, hard work, tolerance and faith are germane to stabilizing national life. These values according to him are important for determining the development and progress of a nation. The values regulate the life of the nation and project good image for the country. However, these values are now eroding, resulting into various social, political and economic vices. Corruption is one of these societal vices of the 21 st century. One of the problems facing most Third World, developing countries, including Nigeria today, is corruption. Thus, to a large extent corruption affects development. Currently, Nigerians are facing financial crisis and this has been attributed to mass unemployment and general loss of confidence in the government. The study therefore aims at analyzing the potentials of civic learning for combating current social, political and eroded value system in Nigeria. Ajitoni and Omoniyi (2017) examined value education: essential tool for socio-political and economic development in Nigeria. Their paper discussed that the neglect of ethical values, which should form the substratum of any good education, has led to ineffectual, decadent, and poor learning. The duty of every society is to pass on the values enshrined in its scriptures and philosophical text to each generation, in order, that the spirit of its culture lives on. Findings showed that a society with no required values cannot witness peace, growth and development. The paper therefore recommends the core values of democracy which promotes secure physical, emotional and political lives within the society. There is need for a widespread renewal of individual commitment to an active life of principle and societal values like truth, right action, hope, peace and non-violence means of getting things done.

Meroyi, Sotoyinbo and Ajobiewe (2017) carried out a study on civic learning in Nigeria: the logical thinking approach to social and political challenges. The paper examined the issue of civic learning and how its essence can be achieved through logical thinking to bring about desired peace and progress in the society. The paper posts that logical reasoning is essential in demonstrating civic attitudes and that experiential learning is a necessary component by which this can be achieved in learners. Adediran, Lijadu and Olugbuyi (2017) examined teacher's assessment of civic learning as instrument for achieving national economic empowerment and development strategy in Ogun State. The population of the study consists of 2,899 
Social Studies teachers at the Secondary School level in Ogun State, Nigeria. The simple random sampling technique was used to select 365 teachers for the study. The responses to the questionnaire were used to answer research question and test the formulated hypotheses. The result of the study indicates that civic learning is yet to be inculcated in pupils and like fully qualified teachers in the schools, also more than half of the sampled populations tend to have positive rating of the adequacy of their knowledge of civic learning as instruments for achieving NEEDS in Ogun State. The paper recommends that, the stakeholders in Social Studies should create awareness on the teaching of civic learning through seminars, conferences and workshops. Thus, social studies and civic education lay Nigeria's hope of producing effective citizens and forming a cohesive society devoid of corrupt practices among the people. This study therefore examines teacher's perception on social studies and civic education in strengthening the EFCC for corruption eradication on the contemporary Nigerian society.

\section{Objectives of the study}

The objectives of this study are to:

1. Examine the teachers' perception of Social Studies in strengthening EFCC for corruption eradication.

2. Examine the impact of teachers' perception of Social Studies in strengthening EFCC for corruption eradication.

3. Find out if teachers' perception of Social Studies and civic education can strengthen EFCC for corruption eradication in Nigeria.

\section{Research questions}

1. What is the teachers' perception of Social Studies in strengthening EFCC in eradicating corruption in Nigeria?

2. What are the impacts of teachers' positive perception of Social Studies in strengthening EFCC for eradicating corruption in Nigeria?

3. How can teachers' perception of social studies strengthening EFCC eradicate corruption in Nigeria?

\section{Methodology}

The research design used for this study was a survey. The study's population was junior secondary school teachers teaching Social Studies and civic education in secondary schools. Population was all junior secondary school teachers, both male and female, teaching Social Studies and Civic Education in the Odeda local government area of Ogun state. Two hundred and sixty teachers were selected using stratified random sampling method but only 220 questionnaires were used for the analysis due to attrition. The instrument used for data collection was the questionnaire. The questionnaire comprised of two sections, section A and section B. Section A was designed to access the demographic data of the respondents while section B comprised of items on a four-point Likert scale requiring the respondents to indicate the extent of their agreement or disagreement with the statements conveyed by the items. The questionnaire was validated by experts in Measurement and Evaluation from Olabisi Onabanjo University, Ago Iwoye in Ogun State and 
administered by the researchers with the help of three research assistants. To determine the reliability of the instrument, a pilot test was conducted. A total of 50 questionnaires were administered during the pilot. These 50 questionnaires were distributed to Social Studies and Civic Education teachers in Abeokuta North Local Government. The questionnaires were administered twice with an interval of three weeks between the two administrations. The scores were recorded for two administrations. The scores were tabulated and the Pearson Product Moment Correlation Co-efficient was applied and correlation coefficient of 0.72 was obtained. On the basis of the correlation done on the questionnaire items, and the test-rest reliability coefficient computed, the instrument was judged adequate, valid and reliable for the purpose of gathering relevant data for the study. Data were analyzed using t-test and ANOVA statistical tools. The instrument was administered on 200 junior secondary school teachers from the non-participating local government areas. The data generated from the study were analyzed using percentages.

\section{Data Presentation, Analysis, Interpretation of Results and Discussion}

\section{Research question 1}

What are the teachers' perception of Social Studies in strengthening EFCC in eradicating corruption in Nigeria?

Table 1: $\quad$ Teachers' perception of Social Studies in eradicating corruption

\begin{tabular}{|c|c|c|c|c|c|}
\hline \multirow{3}{*}{$\frac{\mathrm{S} / \mathrm{N}}{1}$} & Items & Agree & UD & Disagree & Total \\
\hline & $\begin{array}{l}\text { Teachers } \\
\text { teach } \\
\text { students } \\
\text { about moral, } \\
\text { values, skills }\end{array}$ & 112 & 20 & 88 & 220 \\
\hline & $\begin{array}{l}\text { that they } \\
\text { need to be } \\
\text { of good } \\
\text { citizen }\end{array}$ & $(50.9 \%)$ & $(9.1 \%)$ & $(40 . \%)$ & $(100 \%)$ \\
\hline 2 & $\begin{array}{l}\text { Government } \\
\text { pays } \\
\text { teachers }\end{array}$ & 96 & 18 & 106 & 220 \\
\hline & $\begin{array}{l}\text { well for } \\
\text { their } \\
\text { services to } \\
\text { humanity }\end{array}$ & $(43.6 \%)$ & $(8.2 \%)$ & $(48.2 \%)$ & $(100 \%)$ \\
\hline 3 & $\begin{array}{l}\text { What } \\
\text { teacher } \\
\text { receive as } \\
\text { training } \\
\text { equip them } \\
\text { well for the } \\
\text { services } \\
\text { they offer to } \\
\text { people }\end{array}$ & $(65.5 \%)$ & $(7.7 \%)$ & $(26.8 \%)$ & $(100 \%)$ \\
\hline
\end{tabular}


Item 1 in table 1 -shows that $112(50.9 \%)$ of the respondents agreed that teachers' teach student about moral, value, and skills that they need to be of good citizen, 20 $(9.1 \%)$ were undecided about the matter. Similarly, item 1 in the same table revealed that $96(43.6 \%)$ of the respondents agreed that Ogun state government pays teachers well for their services to humanity, $18(8.2 \%)$ were undecided while $106(48.2 \%)$ disagreed with the assertion. Item 3 indicated that $144(65.5 \%)$ agreed that what teachers receive as training equip them well for the services they offer while 17 $(7.7 \%)$ were undecided about the matter and 59 (26.8\%) agreed with the claims.

\section{Research question 2}

What are the impacts of teachers' positive perception of Social Studies in strengthening EFCC for eradicating corruption in Nigeria?

Table 2: $\quad$ Impacts of teachers' positive perception of Social Studies

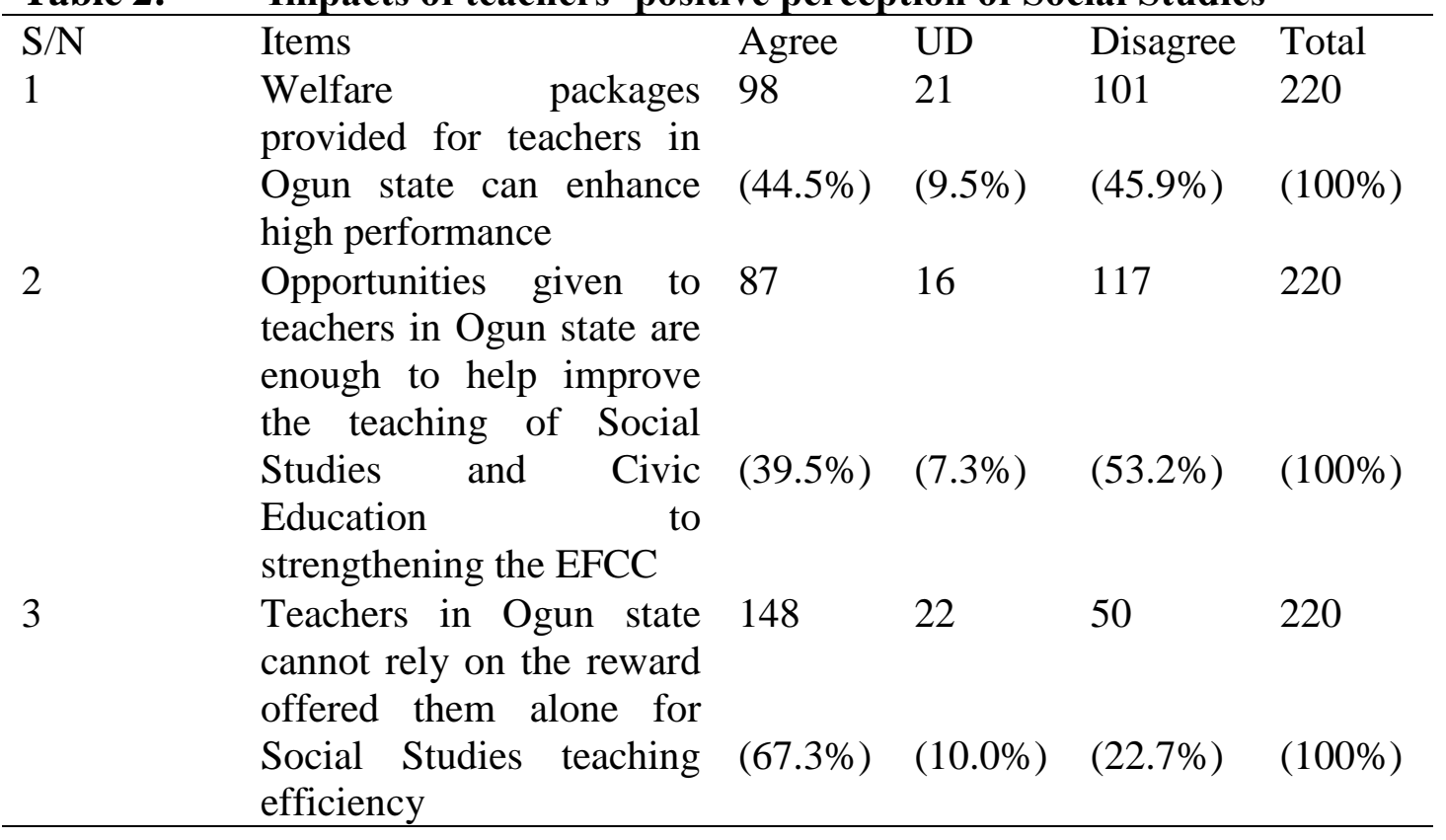

From item 1 in table 2, $98(44.5 \%)$ respondents agreed that welfare packages provided for teachers in Ogun state can enhance high performance. Twenty one respondents (9.5\%) remained undecided while $101(45.9 \%)$ disagreed with the comment. Item 2 revealed that $87(39.5 \%)$ respondents agreed that opportunities given to teachers in Ogun state are enough to help improve the teaching of Social Studies and Civic Education to strengthening the EFCC. Sixteen (7.3\%) were undecided while 117 $(53.2 \%)$ of the respondents disagreed completely with the claims. Furthermore, 148 $(67.3 \%)$ of the respondents who reacted to item 3 agreed that teachers in Ogun state cannot rely on the reward offered them alone for teaching social studies efficiency while $22(10.0 \%)$ took to undecided response pattern, $50(22.7 \%)$ disagreed with assertion.

\section{Research question 3}

How can teachers' perception of Social Studies strengthen EFCC to eradicate corruption in Nigeria? 
Teachers' Perception of Social Studies and Civic Education As Instruments for Strengthening the Fight Against Corrupt Practices in Nigeria

Table 3: $\quad$ Teachers' perception of Social Studies in Strengthening EFCC to eradicate corruption

\begin{tabular}{|c|c|c|c|c|c|}
\hline $\mathrm{S} / \mathrm{N}$ & Items & Agree & UD & Disagree & Total \\
\hline 1 & $\begin{array}{l}\text { Teaching Social Studies can help } \\
\text { in strengthening EFCC to } \\
\text { eradicate corruption in Nigeria }\end{array}$ & $\begin{array}{l}126 \\
(57.3 \%)\end{array}$ & $\begin{array}{l}23 \\
(10.5 \%)\end{array}$ & $\begin{array}{l}71 \\
(32.3 \%)\end{array}$ & $\begin{array}{l}220 \\
(100 \%)\end{array}$ \\
\hline 2 & $\begin{array}{l}\text { I enjoy teaching Social Studies so } \\
\text { as to teach students to be of good } \\
\text { character }\end{array}$ & $(39.1 \%)$ & $\begin{array}{l}32 \\
(14.5 \%)\end{array}$ & $\begin{array}{l}102 \\
(46.4 \%)\end{array}$ & $\begin{array}{l}220 \\
(100 \%)\end{array}$ \\
\hline 3 & $\begin{array}{l}\text { If the government fails to make } \\
\text { teaching of Social Studies more } \\
\text { conditions attractive, I shall still } \\
\text { continue to teach it for better } \\
\text { improvement on students } \\
\text { character }\end{array}$ & $(65.9 \%)$ & $(6.4 \%)$ & $(27.7 \%)$ & $(100 \%)$ \\
\hline
\end{tabular}

Item 1 in table 3 -, show that $126(57.3 \%)$ of the respondents agreed teaching Social Studies will help in strengthening EFCC to eradicate corruption in Nigeria. Twenty 23 respondents $(10.5 \%)$ were undecided about the matter while $1(32.2 \%)$ disagreed. From item 8 in the- table 3, it was established that 86 (39.1\%) agreed that they enjoy teaching Social Studies and Civic Education as to teach students to be of good character. Thirty two respondents (14.5\%) were undecided while 102 (46.4\%) disagreed. Finally, 145 (65.9\%) respondents who answered item 9, agreed that if the government fails to make the teaching of Social Studies and Civic Education more attractive, they would still continue to teach them for better improvement on students characters. Fourteen $(6.4 \%)$ of the respondents could not take any reasonable decision while $61(27.7 \%)$ teachers disagreed with the submission.

\section{Discussion of Findings}

This study examined the impact of Social Studies in strengthening EFCC to eradicate corrupt practices in contemporary Nigeria. The study was meant to investigate whether Social Studies can strengthen EFCC in stopping corrupt practices in Nigeria. In reference to the teachers' responses to the questions, it makes people to understand that Social Studies is a subject that can instill good behavior in students, so that when they grow up, they will be of good character and this will extend to the larger society. Many teachers agreed positively that Social Studies as a societal and interactive subject can help improve the good way in which people understand Social Studies as a better subject that can inculcate moral, value, norms and other virtues that can make people think of better ways of making society a better place to live devoid of corrupt practices.

According to all the question items answered by the teachers, most of them were in agreement that social studies can strengthen EFCC to eradicate corrupt practices in the society. This was in agreement with Haruna and Liman (2013) who said that Social Studies and Civic Education are supportive subjects that can strengthening EFCC in eradicating corruption. It was also in support of Adediran and Ojetunde (2016) report that Social Studies and Civic Education can serve as problem solving subjects that can help in solving societal problems through the effort of EFCC. 


\section{Conclusion}

This study investigated the impact of Social Studies and Civic Education in strengthening EFCC for better performance in eradicating corruption in the society. The study posited that the school management and policy makers can assist in the improvement of teaching of Social Studies and Civic Education in order to instill good character into the students for good behaviour in the nearest future. This study, so far has agreed that the teaching of Social Studies and Civic Education devoid of corruption in the current balance in students attitudes in performance of eradicating corrupt practices in the society for better improvement of a society devoid of corruption. This can be achieved if everybody joins hand together to support EFCC for better performance of eradication of corrupt practices in the society.

The study revealed that Social Studies and Civic Education are capable of reduction if not eradicating of corrupt practices through the inculcation of the right types of values, norms and attitude in the citizenry.

\section{Recommendations}

In line with the findings, the following recommendations were made:

1. Social Studies and civic education should be made compulsory for all secondary school students since the subjects have been identified as potent tools for eradication of corrupt practices.

2. Government should improve on the teaching of Social Studies and civic education in all school system by providing necessary instructional facilities.

3. Students should adhere to the teachings of Social Studies and civic education given by their teachers for better behaviour in the society.

4. Social Studies and civic education teachers should source for rich information and instructional materials from the internet to enhance the teaching/learning of Social Studies and civic education.

5. Workshops, seminars and conferences should be organized for Social Studies and civic education teachers in order to improve their knowledge and widen their horizon in the field. 


\section{References}

Adediran, A. A. \& Ojetunde, S. O. (2016). Social studies and counselling as means of curbing terrorism and militarism for National harmony and peaceful coexistence in Nigeria. A paper presented at the $4^{\text {th }}$ faculty of education international conference, between $17^{\text {th }}-20^{\text {th }}$ May 2016 in the Lagos State University.

Adediran, A. A., Lijadu, M. O. \& Olugbuyi, K. O. (2017). Teachers' Assessment of civic learning as instrument for achieving national economic empowerment and development strategy in Ogun State, Nigeria. Journal of Social Studies and Civic Educators, $\mathbf{X X}(1)$ : 158 - 166.

Ajitoni, O. S. \& Omoniyi, T. O. (2017). Value education: essential tool for sociopolitical and economic development in Nigeria. Nigerian Journal of Social Studies, XX (1) 25 - 39.

Baruwa, B. B. \& Adediran, A. A. (2014). The impact of EFCC in curbing corrupt practices to sustain good government in Nigeria. A paper presented at the COEASU south- west academic conference held at Kwara state college of education on $10^{\text {th }}-14^{\text {th }}$ November 2014.

Ejike, S. (2012). How to tackle corruption effectively in Nigeria. A paper presented at the Pre-convocation Ceremony of University of Nigeria Nsukka, Enugu State, Nigeria.

Haruna, M. S. \& Liman, B. M. (2013). The role of Social Studies education in eradicating terrorism and militarism in Nigeria; Implication for Nigerian government. Nigeria journal of Social Studies and Civic Education. 15 (1): 121-128.

Iyewarun, O. E. (2001). Teaching the ideal of Social Studies for national rebirth and sustainable democracy in Nigeria. In B. Fasanimi, and F. O. Ogunsanye (ed), Nigeria and the challenges of moral education. Ibadan: NPS Educational Publishers Ltd.

Meroyi, S. I., Sotoyinbo, A. O. \& Ajobiewe, A. A. (2017). Civic Leaning in Nigeria: The Logical Thinking Approach to Social and Political Challenges. Journal of Philosophy of Education, 6 (2): 54 - 63.

Okam, C. C. (2009). Exploring civic education for effective citizenship in the task of nation building in Nigeria. Nigerian Journal of Social Studies, XIV (1): 6 - 7.

Oladimeji, T. A. O. (2017) Corruption and economic recession: the need for civic learning. Nigerian Journal of Social Studies, xix (1): 8 - 15.

Yusuf, A. (2005). Effects of corruption instructional strategy on students' performance in social studies. Nigeria Journal of Social Studies, (1 and 2): 223-26. 